ARTICLE

Received 19 Aug 2014 | Accepted 27 Feb 2015 | Published 10 Apr 2015

DOI: $10.1038 /$ ncomms7809

OPEN

\title{
Plant macrofossil evidence for an early onset of the Holocene summer thermal maximum in northernmost Europe
}

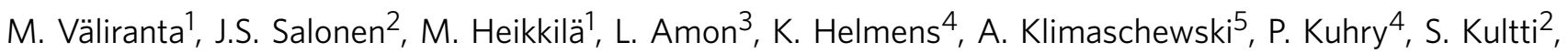
A. Poska ${ }^{3,6}$, S. Shala ${ }^{4}$, S. Veski ${ }^{3} \&$ H.H. Birks ${ }^{7}$

Holocene summer temperature reconstructions from northern Europe based on sedimentary pollen records suggest an onset of peak summer warmth around 9,000 years ago. However, pollen-based temperature reconstructions are largely driven by changes in the proportions of tree taxa, and thus the early-Holocene warming signal may be delayed due to the geographical disequilibrium between climate and tree populations. Here we show that quantitative summer-temperature estimates in northern Europe based on macrofossils of aquatic plants are in many cases ca. $2^{\circ} \mathrm{C}$ warmer in the early Holocene $(11,700-7,500$ years ago) than reconstructions based on pollen data. When the lag in potential tree establishment becomes imperceptible in the mid-Holocene (7,500 years ago), the reconstructed temperatures converge at all study sites. We demonstrate that aquatic plant macrofossil records can provide additional and informative insights into early-Holocene temperature evolution in northernmost Europe and suggest further validation of early post-glacial climate development based on multi-proxy data syntheses.

\footnotetext{
${ }^{1}$ Department of Environmental Sciences, ECRU, University of Helsinki, P.O. Box 65, Helsinki Fl-00014, Finland. ${ }^{2}$ Department of Geosciences and Geography, University of Helsinki, P.O. Box 65, Helsinki FI-00014, Finland. ${ }^{3}$ Institute of Geology, Tallinn University of Technology, Ehitajate tee 5, Tallinn 19086, Estonia. ${ }^{4}$ Department of Physical Geography, Stockholm University, Stockholm 106 91, Sweden. ${ }^{5}$ School of Geography, Archaeology and Palaeoecology, Queen's University, Belfast, Northern Ireland BT7 1NN, UK. ${ }^{6}$ Department of Physical Geography and Ecosystem Analysis, Lund University, Sölvegatan 12, Lund 223 62, Sweden. ${ }^{7}$ Department of Biology and Bjerknes Centre for Climate Research, University of Bergen, P.O. Box 7803, Bergen N-5020, Norway. Correspondence and requests for materials should be addressed to M.V. (email: minna.valiranta@helsinki.fi).
} 
G lacial climate warmed irregularly during the last glacial termination (late glacial, ca. 14,700-11,700 cal $\mathrm{BP}(\mathrm{BP}=$ before $1950 \mathrm{AD}))$ and then warmed rapidly to interglacial values after the start of the Holocene. During the first Holocene millennia, summer temperatures were up to $2{ }^{\circ} \mathrm{C}$ higher than today (Holocene Thermal Maximum). This was most strongly marked at high northern latitudes due to orbital variations that resulted in high summer insolation. After the main ice sheet had melted and the North Atlantic circulation had stabilized in interglacial mode, summer temperatures exceeded those of today, peaking between $c a$. 9,000 and 7,500 cal year $\mathrm{BP}^{1}$.

Most early Holocene temperature reconstructions are derived from fossil terrestrial-pollen assemblages that exclude local elements such as aquatic plants and assume that the pollen record reflects the regional vegetation and therefore climate changes ${ }^{2,3}$. They do not take into account the delay in tree range expansion in response to early Holocene climate warming due to the long population doubling times and relatively slow spread of trees ${ }^{4}$.

In his classic work on the late-glacial flora of Denmark, Iversen ${ }^{5}$ proposed that aquatic plants may provide a more accurate temporal record of the late-glacial and early post-glacial climate changes than trees due to their more rapid dispersal rates. However, studies on the post-glacial dispersal history of aquatic plants are very rare. Pollen records show that aquatic plants closely followed the melting ice-margin and reached their modern ranges in North America during the early Holocene ${ }^{6,7}$. As quantitative climate reconstructions using aquatic-macrophyte data are scarce (see refs 8,9), the climate-indicator value and broad-scale dispersal dynamics of aquatic plants in the Holocene are still poorly understood ${ }^{10,11}$. Modern studies suggest that bird transport and spreading along water systems ${ }^{11}$ are the main and fastest means of dispersal. Early Holocene macrofossil records from lake sediments are often characterized by relatively diverse aquatic plant assemblages $8,12,13$ implying rapid early-Holocene colonization during a period when terrestrial pollen assemblages may reflect vegetation that is out of equilibrium with climate and with low diversity, and possibly low productivity ${ }^{14}$.

Holocene pollen-based summer temperature reconstructions from northern Europe are predominantly driven by changes in the major arboreal pollen taxa ${ }^{2}$, and inferred rises in temperature typically coincide with increases in certain tree-pollen taxa, such as spruce (Picea abies) in north-eastern European Russia ${ }^{15}$, pine (Pinus sylvestris) in northern Fennoscandia ${ }^{16}$ and deciduous trees (Alnus incana, Alnus glutinosa, Ulmus glabra, Corylus avellana, Tilia cordata and Quercus robur) in southern Fennoscandia and the Baltic countries ${ }^{17}$ (Supplementary Fig. 1a). We hypothesize that in such tree-pollen-driven temperature reconstructions, the early-Holocene climate warming signal may be delayed as a result of disequilibrium between climate and tree species distribution and population dynamics ${ }^{14,18}$. This possible shortcoming of pollen-based climate reconstructions needs to be examined by independent data, especially at glacial-interglacial transitions, because pollen data are the most commonly used proxy data source in palaeo data-climate modelling intercomparison exercises ${ }^{1,19}$. Suitable independent data to test this hypothesis can be provided by macrofossil records of aquatic plants. Owing to their more rapid response times, aquatic plants may reflect actual temperature changes faster than pollen-based temperature reconstructions.

Pollen-based temperature reconstructions are generally based on pollen-climate calibrations prepared using large data sets of modern pollen (sediment core-top assemblages) and corresponding climate variables (measured climate normals) ${ }^{3,20}$. Instead of proportional down-core data and surface-sediment calibration sets, macrofossil reconstructions can use information about the presence of individual indicator taxa in macrofossil assemblages and their modern distribution ranges and ecological requirements, as demonstrated in Väliranta et al. ${ }^{21}$ for an early-Weichselian interstadial sequence from southern Finnish Lapland (see also refs 5,22-26).

In this study we compile and compare July temperature $\left(T_{\text {jul }}\right)$ reconstructions based on aquatic and telmatic (helophytes) plant macrofossils (henceforth $T_{\text {julM }}$ ), and terrestrial pollen (henceforth $\left.T_{\text {julP }}\right)$. The results support our hypothesis that temperature reconstructions based on macrofossils of aquatic taxa that can spread and respond faster than long-lived trees, detect earlyHolocene temperature rises before pollen-based reconstructions in the study area. The latter are strongly dominated by the rises of pollen of the major tree-pollen taxa, which were still spreading towards their climatic limits and were therefore out of equilibrium with summer temperatures.

\section{Results}

Study location. Finland is relatively flat with low mountains only in the northwest. The oceanity-continentality gradient is not particularly marked today: in general, continentality increases from the southwest (semi-oceanic) to the northeast (semicontinental). Likewise, the precipitation gradient is gradual, with a difference of $c a .200 \mathrm{~mm} \mathrm{a}^{-1}$ between southern and northern Finland. The country stretches over $10^{\circ}$ of latitude, resulting in a pronounced south-north temperature gradient. The $T_{\text {jul }}$ ranges from $\mathrm{ca} .17^{\circ} \mathrm{C}$ in the south-southeast to $\mathrm{ca} .7 .5^{\circ} \mathrm{C}$ in the mountains of western Lapland. As a result, Finland spans several bioclimatic zones; the boreo-nemoral (the southernmost bioclimatic zone characterized by mixed coniferous and broadleaved forests), the boreal (dominated by coniferous forests) and the subarctic vegetation belts (between the boreal zone and the tree line which, in Finland, is formed by mountain birch). Therefore, many plant species reach their northern distribution limits within Finland. Only in the northernmost part of the country are plant distributions limited by elevation-related climatic conditions (orohemiarctic). Unlike many European countries where human activities strongly influence plant distributions, Finland can be considered to be in a relatively natural state. These geographical facts provide an excellent setting to exploit observed modern species-temperature relationships for palaeoecological temperature reconstructions. To facilitate discussion, the study sites (Fig. 1) are regionally clustered as follows: boreonemoral-southern boreal (Lakes Lielais, Nakri, Kankaanjärvi and Laihalampi), oceanic boreal (Kråkenes Lake), northern boreal (Lakes Loitsana and Kipojärvi) and subarctic (Lakes Njargajavri, Korsajavri and Jansvatnet). Their data are supplemented by literature records from lakes Tsuolbma and Toskal in northern Finland, and records from northeastern European Russia where the lakes are located in different bioclimate zones: northernmost boreal taiga (Lake Lleti), arctic tree line (Lake Tumbulovaty) and arctic tundra (Lake Kharinei). In the comparison of the pollen- and macrofossil-based reconstructions, the time frame $11,700-7,500 \mathrm{cal}$ BP is divided into four time windows: $11,700-10,500,10,500-9,500,9,500-8,500$ and $8,500-7,500$ cal BP.

Site-specific and regional $T_{\text {jul }}$ reconstructions. The timewindow values derived for $T_{\text {julM }}$ and $T_{\text {julp }}$ are shown in Fig. 2a. Full site-specific reconstructed $T_{\text {jul }}$ curves are presented in Supplementary Fig. 2.

Before the time-window 8,500-7,500 cal BP, almost all $T_{\text {julM }}$ reconstructions show warmer temperatures than $T_{\text {julp }}$ in all study regions, although some sites, especially in Russia, occasionally show slightly negative anomalies (Fig. 2b). In Russia, the positive 


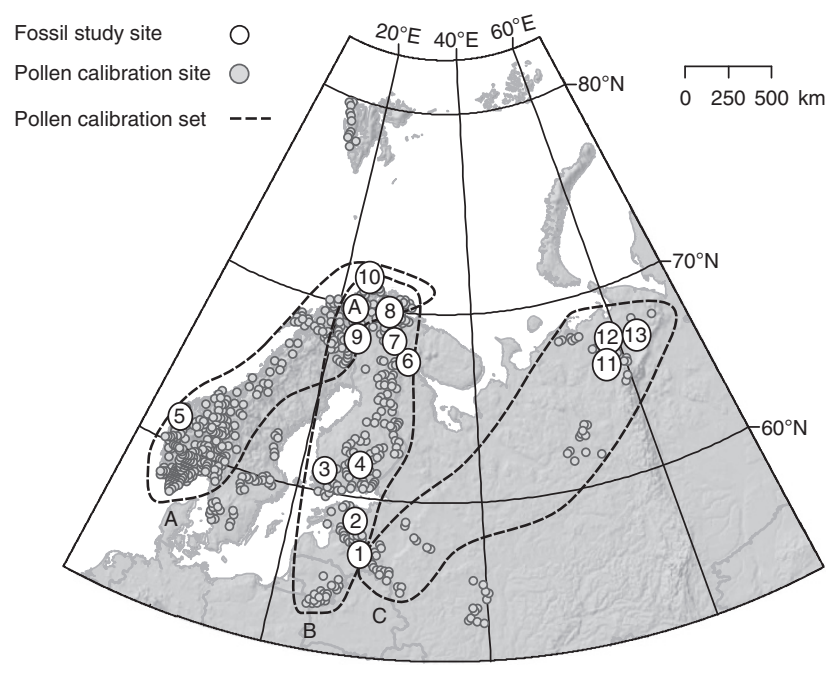

Figure 1 | Locations of the study sites. The 13 study sites selected represent four different biomes: boreonemoral, southern boreal, northern boreal and subarctic-arctic vegetation zones. Fossil pollen and macrofossil study sites are indicated with numbered circles. (1) Lielais Svetinu,

(2) Nakri, (3) Kankaanjärvi, (4) Laihalampi, (5) Kråkenes Lake, (6) Loitsana, (7) Kipojärvi, (8) Njargajavri, (9) Korsajavri, (10) Jansvatnet, (11) Llet-Ti,

(12) Tumbulovaty and (13) Kharinei. See Supplementary Table 1 for details and references about these sites. The study site locations with pollen data adopted from the literature, Lake Tsuolbma ${ }^{16}$ and Toskal ${ }^{67}$, are indicated by capital letter A. The pollen-climate calibration data sets were selected from the 583-sample surface-pollen data set of Salonen et al. ${ }^{59}$, marked with small circles. To represent the modern pollen-climate relationships in the continentality regimes of different fossil sites, three different subsets (A: low continentality, B: intermediate continentality, C: high continentality) were selected from all the surface pollen assemblages. The modern $T_{\text {jul }}$ gradient varies from $17.7^{\circ} \mathrm{C}$ (Latvia) to $7.5^{\circ} \mathrm{C}$ (northern Fennoscandia) and the annual precipitation varies between $1,280 \mathrm{~mm}$ (west coast of Norway) and $500 \mathrm{~mm}$ (Finnish Lapland). The elevation range of the sites is 38-705 m.a.s.l.

anomalies are also slightly smaller, $1-2{ }^{\circ} \mathrm{C}$, than elsewhere for the earliest part of the Holocene. Overall, the largest positive $T_{\text {jul }}$ anomalies occur in the north and the difference becomes smaller towards the mid-Holocene (Fig. 2 and Supplementary Fig. 2).

It should be mentioned that a few subarctic macrofossil records from Finland are fragmented as the sedimentation was discontinuous, probably due to fluctuations in water level. For example, Lake Njargajavri was filled by aquatic bryophytes at $c a$. $10,500 \mathrm{cal} \mathrm{BP}$ and sedimentation stopped for an unknown period of time ${ }^{27}$. Nevertheless, macrofossils suggest higher temperatures than pollen for the earliest intervals in such records, with $T_{\text {julM }}$ in subarctic Finnish Lapland $>13^{\circ} \mathrm{C}$ since ca. $11,000 \mathrm{cal} \mathrm{BP}$, when sedimentation started, while $T_{\text {julP }}$ was around $10-11^{\circ} \mathrm{C}$ or less (Fig. 2a).

Supplementary Fig. 3 illustrates the regional-scale earlyHolocene temperature development through time windows. In all regions, $T_{\text {julM }}$ are higher than $T_{\text {julP }}$ for the earliest time windows. Moreover, towards mid-Holocene only in the boreonemoral and southern boreal regions do the $T_{\text {julp }}$ temperatures exceed $T_{\text {julM }}$, but it should be noted that for 9,500-8,500 and 8,500-7,500 cal BP time windows, macrofossil data are available only from Southern Finland.

\section{Discussion}

Recently, post-glacial tree migration-rate estimates have been revised in the light of emerging macrofossil evidence for the persistence of small tree populations in central and northern
Europe, the Baltic region and European Russia during the Last Glacial Maximum and the Late Glacial (14,500-11,700 cal BP $)^{28-33}$. The previous fast migration rate estimates (100$1,000 \mathrm{~m}$ per year), calculated on tree population spread from southern European refugia ${ }^{34}$, have been reduced to $60-260 \mathrm{~m}$ per year $^{35}$. Trees reached our study sites at different times during the early Holocene (Supplementary Fig. 1b). Pollen and macrofossil records from northeastern European Russia ${ }^{30}$ show that the response times of small northern tree populations to climatic change can be in the order of many centuries. However, faster response times have been reported from the Baltic region during the last glacial-interglacial transition and the 8.2-ka cold event $^{28,29,36}$.

The glaciation histories of Fennoscandia, the Baltic region and European Russia differ considerably. Northern European Russia has been ice-free for the last ca. 90,000 years ${ }^{37}$. In the Baltic region, deglaciation and the following phases of the ancient Baltic Sea led to a slow emergence of land since $c a .15,000 \mathrm{cal} \mathrm{BP}^{38}$ (Fig. 2). Here, macrofossil evidence indicates that populations of tree birch (Betula pendula), pine (P. sylvestris) and aspen (Populus tremula) were present very close to the melting margin of the Fennoscandian Ice Sheet from 14,000 to $13,500 \mathrm{cal}$ BP, while spruce $(P$. abies $)$ immigrated at ca. $12,500 \mathrm{cal} \mathrm{BP}^{28,29,39}$. In addition, broad-leaved trees spread to the Baltic region in the early Holocene around 10,500-10,000 cal BP when the Fennoscandian Ice Sheet was reduced to a small area in northern Fennoscandia ${ }^{17,40}$. Hence, the influence of treepopulation development and migration lags on the pollen-based reconstructions may be less pronounced in the Baltic region than further north.

In northeastern European Russia, $T_{\text {julp }}$ and $T_{\text {julM }}$ show more similar temperature development. Macrofossils infer the same or slightly higher regional $T_{\text {julM }}$ than $T_{\text {julP }}\left(<15^{\circ} \mathrm{C}\right)$ (Fig. 2$)$ for the earliest Holocene up to $7,500 \mathrm{cal} \mathrm{BP}$. Independent $T_{\text {jul }}$ reconstructions from chironomid data of $>14^{\circ} \mathrm{C}$ from one of our sites, the tundra Lake Kharinei $^{41}$ (13 on Fig. 1) support the $T_{\text {julM }}$ reconstructions at around $15^{\circ} \mathrm{C}$. In addition, macrofossil data at sites to the southwest in Karelia and the Yaroslavl' region also suggest early-Holocene $T_{\mathrm{jul}}$ up to $15^{\circ} \mathrm{C}$ (refs 13,42 ). We note that in Russia our macrofossil-derived $T_{\text {julM }}$ of $15.7^{\circ} \mathrm{C}$ is solely due to the presence of Typha seeds. At present, Typha latifolia and Typha angustifolia have very clear distribution ranges that seem to follow regional climate parameters (Supplementary Fig. 4, Den Virtuella floran; http://innaeus.nrm.se/flora/welcome.html). The northern limit of continuous T. latifolia presence corresponds to ca. $17^{\circ} \mathrm{C}$ in more continental European Russia (Den Virtuella floran), whereas our reconstructed temperatures are based on plant distributions in Finland. Typha is often one of the first taxa detected in macrofossil records ${ }^{13}$ (Supplementary Fig. 5). It is a very prolific, wind-dispersing, early successional taxon. It can rapidly colonize new areas, from one seed to $58 \mathrm{~m}^{2}$ cover in 2 years in suitable habitats ${ }^{43}$. Moreover, if the reported current distribution range of Elatine hydropiper in European Russia (Den Virtuella floran) is accurate, its presence at $c a .11,000 \mathrm{cal} \mathrm{BP}$ in the Lake Kharinei sequence would also indicate $T_{\text {julM }}$ greater than $17^{\circ} \mathrm{C}$, supporting the climatic inferences provided by the presence of Typha. Therefore, if Russian distribution data are used, early Holocene $T_{\text {julM }}$ was $c a .2^{\circ} \mathrm{C}$ higher than $T_{\text {julP }}$. This highlights a difficulty posed by obtaining reliable and detailed distributional data and their correlation with reliable meteorological data. As mentioned, temperature limits tend to become higher in more continental areas and regional variation should ideally be taken into account.

The most striking difference between the macrofossil- and pollen-based reconstructions is exhibited in subarctic and northern boreal Fennoscandia, with macrofossils inferring $2{ }^{\circ} \mathrm{C}-4{ }^{\circ} \mathrm{C}$ 
a
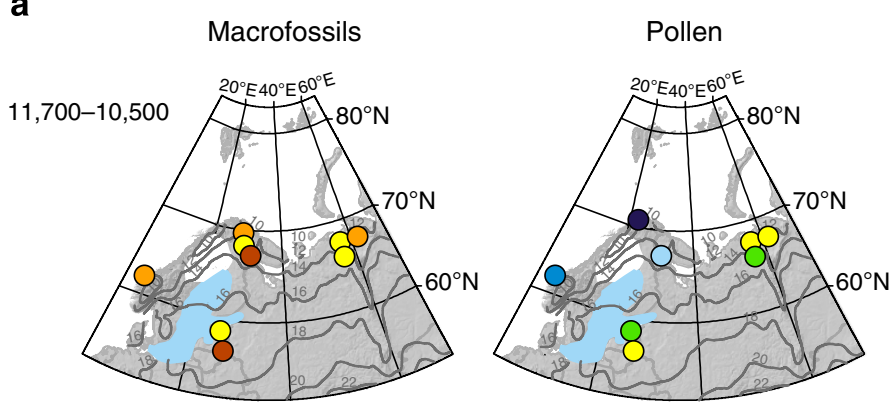

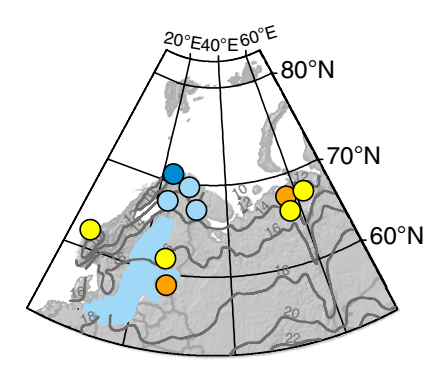

b Temperature anomaly macrofossils versus pollen

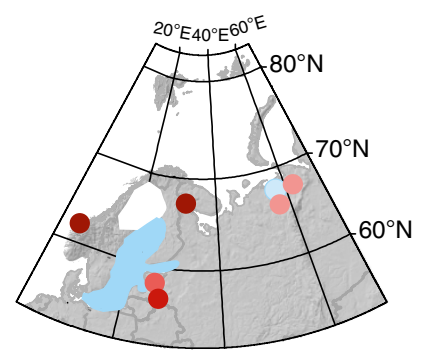

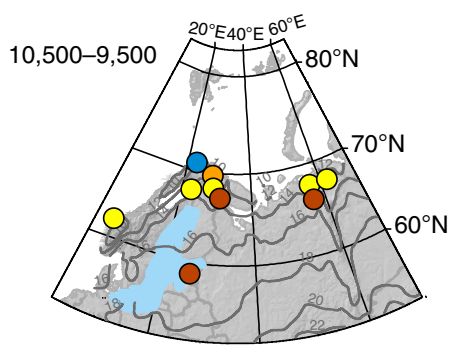
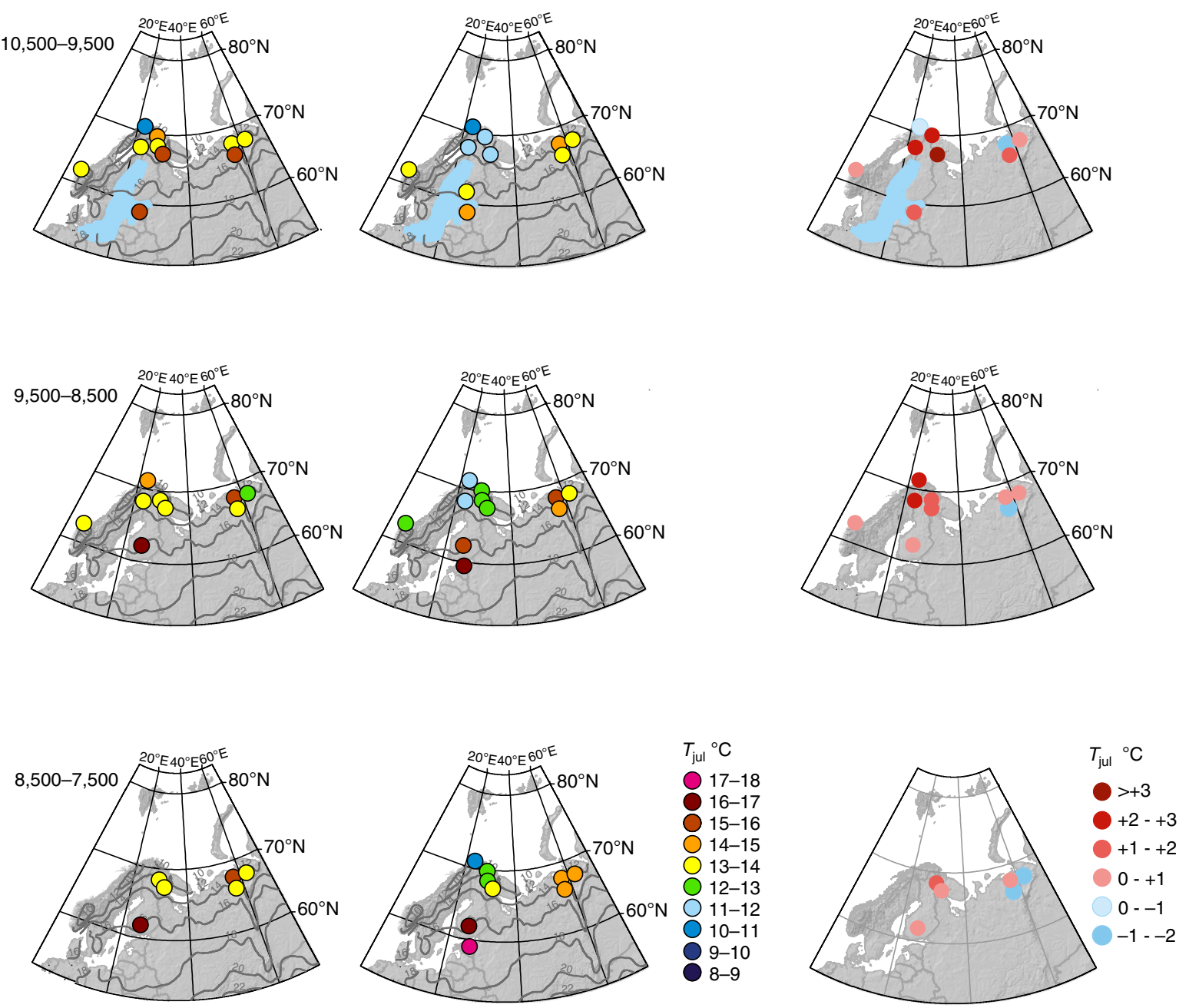

0500
$\mathrm{~km}$

Figure 2 | A comparison of macrofossil- and pollen-based mean $\boldsymbol{T}_{\text {jul }}$ in northern Europe for the four early post-glacial time windows. It should be noted that in Russia, the mean s.e. for pollen are somewhat higher at $1.05-1.15^{\circ} \mathrm{C}$, probably because the Russian calibration data set is smaller and the speciesresponse estimates are thus less certain. (a) The spatio-temporal pattern of macrofossil- and pollen- based mean July temperatures ( $T_{\text {julP }}$ and $T_{\text {jul }}$, respectively) in early- and mid-Holocene time windows (Supplementary Table 3). The pollen-based $T_{\text {julp }}$ for each site is calculated as the median of all reconstructed values from fossil samples dating to the time window in question. The macrofossil-based $T_{\text {julm }}$ is the highest site-specific value for the time window in question (see Methods for details). In addition, essential information about the ice-margin position and post-glacial stages of the Baltic Sea are shown (adapted and modified from ref. 38). Modern $T_{\text {jul }}$ isolines (in grey) are also presented. (b) Temperature anomalies between $T_{\text {jul }}$ and $T_{\text {julP }}$ reconstructions (Supplementary Table 3). Red colour indicates positive anomalies where macrofossil-based temperatures are higher than pollen-based temperatures, while blue colour indicates negative anomalies. Note that pale pink and pale blue spots can both indicate no difference $\left(0^{\circ} \mathrm{C}\right)$. However, it should also be noted that due to the nature of $T_{\text {julM }}$ as a lowest estimate for mean $T_{\text {jul, }}$ negative $T_{\text {julM }}-T_{\text {julP }}$ anomalies are difficult to interpret, as it is impossible to verify whether the anomaly is for instance due to a false absence of macrofossils. In contrast, positive $T_{\text {jul }}-T_{\text {julP }}$ anomalies can be more confidently taken to suggest a negative bias in the $T_{\text {julP }}$ values (see Methods for more detailed methodological discussion and data interpretation). If pollen data were not available from the same lake as macrofossil data, the $T_{\text {julM }}$ was compared with $T_{\text {julP }}$ derived from an adjacent lake from the same climate zone. 
higher temperatures until 8,500 cal BP (Fig. 2). The reconstructions are based on relatively numerous aquatic and other indicative macrofossils. Several aquatic species suggest a $T_{\text {julM }}$ of at least ca. $13-14{ }^{\circ} \mathrm{C}$, but the presence of Typha and Glyceria lithuanica in the northern boreal sites indicates a $T_{\text {julM }}>15^{\circ} \mathrm{C}$.

Macroscopic Scots pine (P. sylvestris) remains show that this species was present in the northern boreal zone from 9,500 cal BP onwards (Supplementary Fig. 1b). The delayed $T_{\text {julp }}$ rise may reflect its late spread and low pollen productivity near its northern $\operatorname{limit}^{44}$. It never reached the highest and the northernmost sites discussed here. In addition, it is possible that the early-Holocene vegetation contained local taxa, such as sedges and grasses whose abundant pollen has a relatively poor temperature-indication value, thus depressing tree percentages and the pollen-based temperature signal. Northern Fennoscandia therefore contrasts with northeastern European Russia and the southern sites where $T_{\text {jul }}$ was higher and boreal trees were already present during the late glacial. The slow northward spread of trees resulted in the greatest discrepancy between $T_{\text {julP }}$ and $T_{\text {julM }}$ in Northern Fennoscandia.

Aquatic plants have the ability to disperse rapidly within their climatic tolerances, and so after major climate warming they will rapidly colonize new suitable habitats. If the recent aggressive spread of the introduced Elodea canadensis in Finland of $>50 \mathrm{~km}$ per decade ${ }^{45}$ is typical, aquatic plants could spread from the Last Glacial Maximum ice-margin in continental Europe to the coast of the Arctic Ocean in about 500 years. High early-Holocene insolation ${ }^{46}$ leading to warm summers combined with the weak summer temperature gradient between $60^{\circ}$ and $70^{\circ} \mathrm{N}$ during the early Holocene ${ }^{47}$ enabled rapid northward spread of aquatic plants. New lake habitats were rapidly colonized through frequent and continuous dispersal and the lack of geographical barriers ${ }^{11}$. In North America ${ }^{6,7}$, aquatic species spread rapidly along the melting ice-sheet margin, reaching their modern distribution ranges early in the Holocene, implying effective reproduction in suitable ecological conditions including warm summer temperatures. This pattern was probably replicated in northern Europe. In contrast, $T_{\text {julp }}$, largely dependent on tree pollen taxa, does not detect this early rapid warming. In contrast to aquatics, long-lived tree species have traits and requirements that lead to relatively slow population establishment with a population doubling time of 20-500 years ${ }^{4}$, low pollen production at distribution limits ${ }^{44}$ and soil requirements that were not met immediately after the ice-sheet melted ${ }^{48}$.

Holocene summer temperatures in the Northern Hemisphere follow the gradually decreasing orbitally forced summer insolation after $11,000 \mathrm{cal} \mathrm{BP}^{46}$. However, the peak warmth of Holocene summers, depending on the model or proxy used, is often proposed to begin $c a$. 9,000-7,000 cal BP and last until $c a$. $5,000 \mathrm{cal} \mathrm{BP}$, and is attributed to the dynamics of the Laurentide and Greenland ice sheets ${ }^{1,19,49}$. In contrast, macrofossil data from European high latitudes suggest an earlier start of the warming (Fig. 2) and indicate that the modern $T_{\text {jul }}$ often exceeded between 11,500 and $8,500 \mathrm{cal} \mathrm{BP}^{22,50-52}$, earlier than in the pollen-based reconstructions (Fig. 2 and Supplementary Fig. 2).

Independent evidence supports the concept of a warm early Holocene in northernmost Europe. This includes chironomidbased temperature reconstructions from Kola Peninsula, northeast European Russia and northern Fennoscandia ${ }^{9,22,41,50,53}$, diatom and geochemical data from northeast European Russia ${ }^{54}$, macrofossil data from Karelia and western Russia ${ }^{13,42}$, and seasurface temperature reconstructions from the northern North Atlantic ${ }^{52,55}$. It is important to verify the early Holocene warming and thermal maximum inferred from aquatic macrofossils by a systematic comparison with independent evidence. How general is our inference that the early Holocene was warmer than previously thought? More multi-proxy studies from northern Europe are needed to verify the patterns appearing from the present rather limited data. As with all biological proxies, there are drawbacks associated with macrofossil data, mainly the relatively few macrofossils usually retrieved compared with pollen grains, and the large number of potential false absences due to low macrofossil production, limited dispersal and preservation. However, macrofossils can frequently be identified to species level, which makes it possible to use indicator species, as we have done here. It is also important to critically assess palaeoclimatic reconstructions, being aware of their merits and their drawbacks, so that they can be used to validate model simulations of palaeoclimate, especially in periods of rapid climate change such as during the late-glacial and early-Holocene periods ${ }^{56}$.

In summary, the lake-sediment plant-macrofossil $T_{\text {julM }}$ from boreo-nemoral to subarctic zones of northern Europe, consistently indicate a warm $\left(>13^{\circ} \mathrm{C}\right)$ early-Holocene exceeding modern $T_{\text {jul }}$ by about $2^{\circ} \mathrm{C}$ in high latitudes until ca. 7,500 cal BP. Aquatic and telmatic plants probably responded rapidly to the Holocene warming, closely following the melting ice margin. Even scarce aquatic macrofossil finds testify to the local presence of the plant and can be used as indicator species to reconstruct $T_{\text {jul }}$. Pollen-based $T_{\text {julp }}$ are often lower and modern values were exceeded later than in the macrofossil records. The difference between early-Holocene pollen- and macrofossil-based temperature estimates was largest in northernmost Fennoscandia and lasted until $8,500 \mathrm{cal} \mathrm{BP}$ when boreal trees spread into the area. Differences in the boreo-nemoral and southern boreal sites were smaller but consistent at the very beginning of the Holocene. This geographical pattern probably reflects the relatively slow northward spread and establishment of trees whose pollen records substantially influence $T_{\text {julP }}$, thus causing an underestimate in the pollen-based early-Holocene temperatures due to non-climatic factors reflected in the fossil pollen assemblages. Towards the mid-Holocene, the reconstructed $T_{\text {julP }}$ and $T_{\text {julM }}$ converge in all study sites.

The discovery of the discrepancy between macrofossil and pollen reconstructions has implications for palaeoclimate history in northern Europe; perhaps, the impacts of high summer insolation during the early Holocene have been underestimated, especially in the Arctic. This result needs validating by more multi-proxy studies involving pollen and macrofossils, and also by other independent proxies capable of providing a summer temperature reconstruction, such as chironomid records. Simulations from palaeoclimate models to reconstruct climate processes over the last glacial termination are frequently validated against pollen-inferred temperatures. If early-Holocene temperatures really were higher than those reconstructed from pollen data, this modifies our understanding of climate evolution from lateglacial to early-Holocene conditions. Palaeoclimate models will have to be reassessed and validated against the new palaeoclimate scenario. If the models can successfully reproduce past climate changes, we can be more certain of future climate predictions made by the models.

\section{Methods}

Material. The sediment sequences derived from several sites are located in Fennoscandia, the Baltic region and northeastern European Russia (Fig. 1 and Supplementary Table 1), and span the early Holocene period from 11,700 to $7,500 \mathrm{cal}$ BP. We first use the modern Finnish plant species distribution data in combination with meteorological climate normals (Supplementary Fig. 4 and Supplementary Table 2) to identify the species-specific current lowest requirement for mean $T_{\text {jul. }}$ These limiting temperature values are used to reconstruct macrofossil-based mean $T_{\text {jul }}$. It should be noted that this procedure can only provide a lowest mean $T_{\text {jul }}$ estimate. Age-depth models based on calibrated ${ }^{14} \mathrm{C}$ dates are available for almost every site (Supplementary Methods) and these original models are applied in this study. 
Pollen-based mean $\boldsymbol{T}_{\text {jul }}$ reconstructions. Pollen-based $T_{\text {jul }}$ reconstructions are derived using two-component weighted averaging-partial least squares calibration model ${ }^{57}$. Three regional pollen-climate calibration data sets were used (Fig. 1), selected from the surface-sample data set of Salonen $e t$ al..$^{58}$ and covering different sections of northern Europe. With each fossil data set, the regional calibration data set containing the fossil site was used, to best represent the climatic responses of taxa within the region in question ${ }^{59,60}$. The performance of each calibration model was tested by leave-one-out cross-validation, suggesting a root-mean-square error of predictionof $1.13^{\circ} \mathrm{C}$ with calibration data set $\mathrm{A}, 0.83^{\circ} \mathrm{C}$ with set $\mathrm{B}$ and $0.84^{\circ} \mathrm{C}$ with set C. Sample-specific s.e. were estimated for the reconstructed values using bootstrapping ${ }^{61}$ (100 iterations). The time-window-specific $T_{\text {julP }}$ value for each site is calculated as the median of all reconstructed values from fossil samples dating to the time window in question. Reconstructions were prepared in $\mathrm{C} 2$ software ${ }^{62}$ using all terrestrial pollen and spore taxa, and square-root-transformed species data.

Macrofossil-based $\boldsymbol{T}_{\text {jul }}$ reconstructions. A unique modern species-specific spatial plant distribution data set (http://www.luomus.fi/kasviatlas) ${ }^{63}$ covers the whole of Finland and long-term meteorological climate normals are readily available ${ }^{64}$ (Supplementary Fig. 4 and Supplementary Table 2). The plant distribution database can be used to correlate modern species distributions with climate variables, as it is based on continuous botanical surveys. The database is frequently updated and contains over 5.8 million observations, the earliest of which go back to the late nineteenth century.

The macrofossil taxa listed below were used to reconstruct temperature. The modern lowest $T_{\text {jul }}$ limit $\left({ }^{\circ} \mathrm{C}\right)$ is indicated in brackets (see also Supplementary Table 2). References are ref. 63 and ref. 64, if not stated otherwise: Cristatella mucedo (bryozoan remain; $\left.10^{\circ} \mathrm{C}\right)^{65}$, Nuphar $\left(13.14^{\circ} \mathrm{C}\right)$, Nymphaea $\left(13.49^{\circ} \mathrm{C}\right)$, narrow-leaved Potamogeton spp. (a combination of species such as Potamogeton pusillus, Potamogeton rutilus and Potamogeton friesii; $\left.13.61^{\circ} \mathrm{C}\right)$, Potamogeton compressus $\left(13.85^{\circ} \mathrm{C}\right)$, Callitriche cophocarpa $\left(13.65^{\circ} \mathrm{C}\right)$, Callitriche hermaphroditica $\left(14^{\circ} \mathrm{C}\right)$, Ceratophyllum $\left(14.11^{\circ} \mathrm{C}\right)$, Elatine hydropiper $\left(14.24^{\circ} \mathrm{C}\right)$, Typha latifolia $\left(15.69^{\circ} \mathrm{C}\right)$, Glyceria lithuanica $\left(15.65^{\circ} \mathrm{C}\right)$, Najas flexilis $\left(16.75^{\circ} \mathrm{C}\right)$.

When Potamogeton species were not originally identified to species level, we assumed that species assemblages were similar to those detected at the other northern study sites (Supplementary Fig. 5) and we assigned a cautious tentative $T_{\text {jul }}$ lowest inference value of $13.5^{\circ} \mathrm{C}$. One of the detected species in Russia was E. hydropiper, which, according to den Virtuella floran, does not currently occur in northeastern European Russia at all, as it is restricted to the western and southwestern parts of European Russia, mainly south of $60^{\circ} \mathrm{N}$. This distribution map is unlikely to be accurate but justifies the use of the Finnish distributional data, with an option that in more continental Russia the presence of this species might indicate values higher than $13^{\circ} \mathrm{C} T_{\text {jul }}$. The other taxon that should be mentioned in this context is Typha. T. latifolia has a more northern distribution range than T. angustifolia, and because Typha seeds cannot be identified to species level we assume that the species in fossil records is T. latifolia. In European Russia the northern limit of the continuous presence of T. latifolia follows $c a .17^{\circ} \mathrm{C}$ isotherm, whereas in Finland the restricting $T_{\mathrm{jul}}$ is $15.69^{\circ} \mathrm{C}$. Here we use the $T_{\text {jul }}$ value from Finland as for all other species.

Even though the macrofossil-derived reconstructions are not continuous in the same way as pollen reconstructions-they are based on the presence of indicator species and often samples do not contain any remains that may be used to infer temperature-the temperature reconstructions are displayed as interpolated (dashed) lines to facilitate comparison with the pollen-climate reconstructions (Supplementary Fig. 2).

The macrofossil-based $T_{\text {jul }}$ reconstruction includes the following steps: first, the most indicative aquatic or lake-shore plant species were selected from the original macrofossil assemblages (Supplementary Fig. 3). Next, modern species distribution observations ${ }^{63}$ and a mean $T_{\text {jul }}$ derived from the same grid cells, based on daily measurements (1970-2000) by the Finnish Meteorological Institute ${ }^{64}$, were used to estimate current species-specific $T_{\text {jul }}$ limits (Supplementary Fig. 4 and Supplementary Table 2). The species-specific $T_{\mathrm{jul}}$ limit was estimated as the median of the mean $T_{\text {jul }}$ values in grid cells containing individual species occurrences along the northernmost modern distribution limit. The $T_{\text {julm }}$ palaeo-curve (Supplementary Fig. 2) was then created based on the macrofossil assemblages using the lowest requirements for mean $T_{\text {jul }}$ for the fossil taxa found. For $T_{\text {julM }}$ estimates for each time window (Fig. 2), we selected that taxon from the assemblages, which has the highest modern mean $T_{\text {jul }}$ limit in the north. For example, if samples within the 9,500-8,500 cal BP time window contained Nymphaea, C. hermaphroditica and Typha seeds, the 9,500-8,500 cal BP timewindow $T_{\text {jul }}$ was derived as the modern mean $T_{\text {jul }}$ requirement of Typha, which is higher than that of Nymphaea and C. hermaphroditica.

Assessment of errors. For pollen-based $T_{\text {jul }}$ values, the bootstrap-estimated s.e. vary from sample to sample. The core-specific mean s.e. are $0.85-0.95^{\circ} \mathrm{C}$ for the Fennoscandian and Baltic sites, while for the Russian sites the mean s.e. are somewhat higher at $1.05-1.15^{\circ} \mathrm{C}$, probably because the Russian calibration data set is smaller and the species-response estimates are thus less certain. In practice, pollen-based reconstructions tend to have a significant amount of sample-tosample noise (see for example, Supplementary Fig. 1a), for example, due to the random variability in (a) the selection of pollen grains for the sample count, (b) taphonomic processes and (c) non-climatic factors affecting pollen production. For this reason, the climatic value of a single pollen assemblage can be dubious; hence, pollen-based stratigraphic reconstructions are commonly smoothed using locally weighted regression, as is done here (Supplementary Fig. 2). To derive the time-window-specific $T_{\text {julp }}$ value, we used the median of the sample-specific $T_{\text {jul }}$ values falling within the time window, to represent a typical pollen-based $T_{\text {jul }}$ value within the time window. In doing this, we assume that the sample-to-sample variation within the time window is largely noise and not real climatic variability, which is probably justified due to the relative shortness of the time windows.

Sample-specific error estimations as with pollen are not possible with the macrofossil indicator species method. However, we consider that the method used here most likely provides an underestimate rather than an overestimate of the reconstructed species-specific mean $T_{\text {jul }}$. The reconstructed species-specific mean $T_{\mathrm{jul}}$ is based on the median of modern mean $T_{\mathrm{jul}}$ observations at grid cells containing individual occurrences at the modern northern species limit. The median value incorporates $T_{\text {jul }}$ values of all individual outlying occurrences, including those that may be situated in unusually favourable microhabitats with an ideal $T_{\text {jul }}$ microclimate and/or an ideal combination of secondary ecologically significant environmental factors. Thus, we consider it improbable that a generally applicable species-specific $T_{\text {jul }}$ requirement would be lower than the value derived here and, by extension, we consider the derived $T_{\text {julM }}$ values to be conservative (that is, low). A measure of the largest conceivable $T_{\text {julM }}$ overestimation can be derived from the differences between the 'median observed' $T_{\text {jul }}$ and the 'lowest observed' $T_{\mathrm{jul}}$ at the northern distribution limit for each species. These median-tolowest differences vary from 0.02 to $1.24^{\circ} \mathrm{C}$, with a mean of $0.50{ }^{\circ} \mathrm{C}$

(Supplementary Table 2). Thus, if the $T_{\text {julM }}$ estimates were based on the absolute lowest $T_{\text {jul }}$ at which the species has been observed-which would almost certainly be an underestimate for the reasons noted above-the $T_{\text {julM }}-T_{\text {julp }}$ anomalies would not fall by more than a few $0.1{ }^{\circ} \mathrm{C}$, and especially the large early-Holocene anomalies of $>2{ }^{\circ} \mathrm{C}$ would remain much higher than the estimated s.e. of the pollen-based reconstruction.

In most cases, the proxies were analysed from the same sediment sections, that is, both proxy data are based on same age-depth models, and uncertainties related to the original chronologies or age-depth model establishment should thus be minor.

Interpretation of reconstructions. It should be noted that the $T_{\text {julM }}$ values derived here represent lowest mean $T_{\mathrm{jul}}$ estimates only, and that possible local presence of any taxa with higher $T_{\mathrm{jul}}$ requirements cannot be excluded based on the absence of macrofossils, due to the possibility of so-called 'false absences' in the plant macrofossil record ${ }^{66}$. By comparison, false absences are not likely with pollen data due to the much greater production and even dispersal of pollen grains compared with macroscopic plant remains, and with $T_{\text {julp }}$ taphonomic processes alone are no more likely to cause a negative bias compared with a positive one. Owing to the nature of $T_{\text {julM }}$ as a lowest estimate for mean $T_{\text {jul }}$, negative $T_{\text {julM }}-T_{\text {julP }}$ anomalies are difficult to interpret, as it is impossible to verify whether the anomaly is due to a false absence of macrofossils requiring greater warmth or some other underlying bias in either the macrofossil or pollen-based technique. By comparison, positive $T_{\text {julM }}-T_{\text {julP }}$ anomalies can be more confidently taken to suggest a negative bias in the $T_{\text {julP }}$ values; especially as for methodological reasons (see previous subsection) the $T_{\text {julm }}$ values are not likely to be substantially overestimated. In our analysis, we thus pay particular attention to the spatiotemporal incidence of situations where the $T_{\text {julM }}$ estimate exceeds the $T_{\text {julp }}$ value (positive $T_{\text {jul }}-T_{\text {julp }}$ anomaly) considerably (by $>2{ }^{\circ} \mathrm{C}$ ), thus strongly suggesting an unaccounted for source of negative bias in the pollen-based reconstruction.

\section{References}

1. Renssen, H., Seppä, H., Crosta, X., Goosse, H. \& Roche, D. M. Global characterization of the Holocene Thermal Maximum. Quat. Sci. Rev. 48, 7-19 (2012).

2. Seppä, H., Birks, H. J. B., Odland, A., Poska, A. \& Veski, S. A modern pollen-climate calibration set from northern Europe: developing and testing a tool for palaeoclimatological reconstructions. J. Biogeogr. 31, 251-267 (2004).

3. Whitmore, J. et al. Modern pollen data from North America and Greenland for multi-scale palaeoenvironmental applications. Quat. Sci. Rev. 24, 1828-1848 (2005).

4. Bennett, K. D. The rate of spread and population increase of forest trees during the Postglacial. Phil. Trans. R. Soc. Lond. B 314, 523-531 (1986).

5. Iversen, J. The Late-Glacial flora of Denmark and its relation to climate and soil. Danmarks Geologiske Undersøgelse II 80, 87-119 (1954).

6. Dieffenbacher-Krall, A. C. \& Jacobson, G. Post-glacial changes in the geographic ranges of certain aquatic vascular plants in North America. Proc. $R$. Irish Acad. B 101, 79-84 (2001).

7. Sawada, M., Viau, A. E. \& Gajewski, K. The biogeography of aquatic macrophytes in North America since the Last Glacial Maximum. J. Biogeogr. 30, 999-1017 (2003). 
8. Väliranta, M. Long-term changes in aquatic plant species composition in North-eastern European Russia and Finnish Lapland, as evidenced by plant macrofossil analysis. Aquat. Bot. 85, 224-232 (2006).

9. Luoto, T., Kaukolehto, M., Weckström, J., Korhola, A. \& Väliranta, M. New evidence of warm early-Holocene summers in subarctic Finland based on an enhanced regional chironomid-based temperature calibration model. Quat. Res. 81, 50-62 (2014).

10. Hu, F. S., Brubaker, L. B. \& Anderson, P. M. Boreal ecosystem development in the Northwestern Alaska Range since 11,000 yr B.P. Quat. Res. 45, 188-201 (1996).

11. Santamaría, L. Why are most aquatic plants widely distributed? Dispersal, clonal growth and small-scale heterogeneity in a stressful environment. Acta Oecol. 23, 137-154 (2002).

12. Birks, H. H. Aquatic macrophyte vegetation development in Kråkenes Lake, western Norway, during the late-glacial and early-Holocene. J. Paleolim. 23, 7-19 (2000)

13. Wohlfarth, B. et al. Unstable early Holocene climatic and environmental conditions in northwestern Russia derived from a multidisciplinary study of a lake sediment sequence from Pichozero, southeastern Russian Karelia. Holocene 14, 732-746 (2004)

14. Birks, H. J. B. \& Birks, H. H. Biological responses to rapid climate change at the Younger Dryas-Holocene transition at Kråkenes, western Norway. Holocene 18, 19-30 (2008).

15. Salonen, J. S. et al. Holocene and lateglacial temperature changes and associated treeline dynamics in NE European Russia. Quat. Res. 75, 501-511 (2011).

16. Seppä, H. \& Birks, H. J. B. July mean temperature and annual precipitation trends during the Holocene in the Fennoscandian tree-line area: Pollen-based climate reconstructions. Holocene 11, 527-537 (2001)

17. Heikkilä, M. \& Seppä, H. Holocene climate dynamics in Latvia, eastern Baltic region: a pollen-based summer temperature reconstruction and regional comparison. Boreas 39, 705-719 (2010).

18. Normand, S. et al. Postglacial migration supplements climate in determining plant species ranges in Europe. Proc. R. Soc. B 278, 3644-3653 (2011).

19. Renssen, H. et al. The spatial and temporal complexity of the Holocene thermal maximum. Nat. Geosci. 2, 411-414 (2009).

20. Davis, B. A. S. et al. The European Modern Pollen Database (EMPD) project. Veget. Hist. Archaeobot. 22, 521-530 (2013).

21. Väliranta, M., Birks, H. H., Helmens, K., Engels, S. \& Piirainen, M. Early Weichselian interstadial (MIS 5c) summer temperatures were higher than today in northern Fennoscandia. Quat. Sci. Rev. 28, 777-782 (2009).

22. Birks, H. H. et al. Late-glacial and early-Holocene climate variability reconstructed from multi-proxy records on Andøya, northern Norway. Quat. Sci. Rev. 89, 1-15 (2014).

23. Isarin, R. F. B. \& Bohncke, S. J. P. Mean July temperatures during the Younger Dryas in northwestern and central Europe as inferred from climate indicator plant species. Quat. Res. 51, 158-173 (1999).

24. Birks, H. H. \& Ammann, B. Two terrestrial records of rapid climatic change during the glacial-Holocene transition (14,000-9,000 calendar years B.P.) from Europe. Proc. Natl. Acad. Sci. USA 97, 1390-1394 (2000).

25. Aarnes, I., Kühl, N. \& Birks, H. H. Quantitative climate reconstruction from late-glacial and early Holocene plant macrofossils in western Norway using the probability density function approach. Rev. Palaeobot. Palynol. 170, 27-39 (2012).

26. Thompson, R. S. et al. Quantitative estimation of climatic parameters from vegetation data in North America by the mutual climatic range technique. Quat. Sci. Rev. 51, 18-39 (2012).

27. Väliranta, M., Kultti, S., Nyman, M. \& Sarmaja-Korjonen, K. Holocene development of aquatic vegetation in a shallow Lake Njargajavri, Finnish Lapland with evidence of water level fluctuations and drying. J. Paleolim. 34, 203-215 (2005)

28. Heikkilä, M., Fontana, S. L. \& Seppä, H. Rapid Lateglacial tree population dynamics and ecosystem changes in the eastern Baltic region. J. Quat. Sci. 24, 802-815 (2009)

29. Veski, S. et al. Lateglacial vegetation dynamics in the eastern Baltic region between 14,500 and 11,400 cal yr BP: A complete record since the Bølling (GI-1e) to the Holocene. Quat. Sci. Rev. 40, 39-53 (2012).

30. Väliranta, M. et al. Scattered late-glacial tree populations as dispersal nuclei for early-Holocene forest development at and beyond the modern treeline in NE European Russia. J. Biogeogr. 38, 922-932 (2011).

31. Wohlfarth, B. et al. Climatic and environmental changes in NW Russia between 15,000 and 8000 cal yr BP: a review. Quat. Sci. Rev. 26, 1871-1883 (2007)

32. Birks, H. J. B. \& Willis, K. J. Alpines, trees, and refugia in Europe. Plant Ecol. Divers. 1, 147-160 (2008).

33. Amon, L., Veski, S. \& Vassiljev, J. Tree taxa immigration to the eastern Baltic region, southeastern sector of Scandinavian glaciation during the Late-glacial period (14,500-11,700 cal. B.P.). Veg. Hist. Archaeobot. 23, 207-216 (2014).

34. Huntley, B. \& Birks, H. J. B. An Atlas of Past and Present Pollen Maps for Europe: 0-13000 Years Ago (Cambridge University Press, 1983).
35. Feurdean, A. et al. Tree migration-rates: narrowing the gap between inferred post-glacial rates and projected rates. PLoS One 8, 1-7 (2013).

36. Amon, L., Veski, S., Heinsalu, A. \& Saarse, L. Timing of Lateglacial vegetation dynamics and respective palaeoenvironmental conditions in southern Estonia: evidence from the sediment record of Lake Nakri. J. Quat. Sci. 27, 169-180 (2012).

37. Svendsen, J. I. et al. Late quaternary ice sheet history of northern Eurasia. Quat. Sci. Rev. 23, 1229-1271 (2004).

38. Wohlfarth, B. et al. Quaternary of Norden. Episodes 31, 73-81 (2008).

39. Stančikaitè, M., Šinkūnas, P., Seirienè, V. \& Kisielienè, D. Patterns and chronology of the Lateglacial environmental development at Pamerkiai and Kašučiai, Lithuania. Quat. Sci. Rev. 27, 127-147 (2008).

40. Saarse, L. \& Veski, S. Spread of broad-leaved trees in Estonia. Proc. Estonian Acad. Sci. 50, 51-65 (2001).

41. Jones, V. J. et al. The influence of Holocene treeline advance and retreat on an arctic lake ecosystem; a multi-proxy study from Kharinei Lake, North Eastern European Russia. J. Paleolim 46, 123-137 (2011).

42. Wohlfarth, B. et al. Late glacial and Holocene palaeoevironmental changes in the Rostov-Yaroslavl' area, West Central Russia. J. Paleolim. 35, 543-569 (2006).

43. Grace, J. B. \& Wetzel, R. G. Habitat partitioning and competitive displacement in cattails (typha): experimental field studies. Am. Nat. 118, 463-474 (1981).

44. Eide, W., Birks, H. H., Bigelow, N. H., Peglar, S. M. \& Birks, H. J. B. Holocene forest development along the Setesdal valley, southern Norway, reconstructed from macrofossil and pollen evidence. Veget. Hist. Archaeobot. 15, 65-85 (2006).

45. Heikkinen, R. K., Leikola, N., Fronzek, S., Lampinen, R. \& Toivonen, H. Predicting distribution patterns and recent northward range shift of an invasive aquatic plant: Elodea canadensis in Europe. BioRisk 2, 1-32 (2009).

46. Miller, G. H. et al. Temperature and precipitation history of the Arctic. Quat. Sci. Rev. 29, 1679-1715 (2010).

47. Berger, A. \& Loutre, M. F. Insolation values for the climate of the last 10 million years. Quat. Sci. Rev. 10, 297-317 (1991).

48. Birks, H. J. B. \& Birks, H. H. The rise and fall of forests. Science 305, 484-485 (2004).

49. Kaufman, D. S. et al. Holocene thermal maximum in the western Arctic (0-180 W). Quat. Sci. Rev. 23, 529-560 (2004).

50. Birks, H. H. et al. From cold to cool in northernmost Norway: Lateglacial and early Holocene multi-proxy environmental and climate reconstructions from Jansvatnet, Hammerfest. Quat. Sci. Rev. 33, 100-120 (2012).

51. Birks, H. H. South to North: contrasting late-glacial and early Holocene climate changes and vegetation responses between south and north Norway. Holocene 25, 37-52 (2015).

52. Eldevik, T. et al. A brief history of climate-the northern seas from the Last Glacial Maximum to global warming. Quat. Sci. Rev. 106, 225-246 (2014).

53. Ilyashuk, E. A., Ilyashuk, B. P., Hammarlund, D. \& Larocque, I. Holocene climatic and environmental changes inferred from midge records (Diptera: Chironomidae, Chaoboridae, Ceratopogonidae) at Lake Berkut, southern Kola Peninsula, Russia. Holocene 15, 897-914 (2005).

54. Cremer, H., Andreev, A., Hubberten, H.-W. \& Wischer, F. Paleolimnological reconstructions of Holocene environments and climate from Lake Lyadhej-To, Ural Mountains, Northern Russia. Arct Antarctic Alp. Res. 36, 147-155 (2004)

55. Hald, M. et al. Variations in temperature and extent of Atlantic Water in the northern North Atlantic during the Holocene. Quat. Sci. Rev. 26, 3423-3440 (2007).

56. Heiri, O. et al. Validation of climate model-inferred regional temperature change for late-glacial Europe. Nat. Commun. 5, 4914 (2014).

57. ter Braak, C. J. F. \& Juggins, S. Weighted averaging partial least squares regression (WA-PLS): an improved method for reconstructing environmental variables from species assemblages. Hydrobiologia 269-270, 485-502 (1993)

58. Salonen, J. S., Seppä, H., Luoto, M., Bjune, A. E. \& Birks, H. J. B. A North European pollen-climate calibration set: analysing the climatic responses of a biological proxy using novel regression tree methods. Quat. Sci. Rev. 45, 95-110 (2012).

59. Salonen, J. S., Helmens, K. F., Seppä, H. \& Birks, H. J. B. Pollen-based palaeoclimate reconstructions over long glacial-interglacial timescales: methodological tests based on the Holocene and MIS $5 \mathrm{~d}-\mathrm{c}$ deposits of Sokli, northern Finland. J. Quat. Sci. 28, 271-282 (2013).

60. Salonen, J. S., Seppä, H. \& Birks, H. J. B. The effect of calibration data set selection on quantitative palaeoclimatic reconstructions. Holocene 23, 1650-1654 (2013).

61. Birks, H. J. B., Line, J. M., Juggins, S., Stevenson, A. C. \& ter Braak, C. J. F. Diatoms and pH reconstruction. Phil. Trans. R. Soc. Lond. B. 327, 263-278 (1990).

62. Juggins, S. C2 version 1.5 user guide. Software for Ecological and Palaeoecological Data Analysis and Visualisation (Newcastle University, Newcastle upon Tyne, 2007).

63. Lampinen, R. \& Lahti, T. 2013: Kasviatlas (Helsingin Yliopisto, Luonnontieteellinen keskusmuseo, 2012). 
64. Venäläinen, A., Tuomenvirta, H., Pirinen, P. \& Drebs, A. A Basic Climate Data Set 1961-2000-Description and Illustrations (Finnish Meteorological Institute, Reports5, 2005).

65. Økland, K. A. \& Økland, J. Freshwater bryozoans (Bryozoa) of Norway: distribution and ecology of Cristatella mucedo and Paludicella articulata. Hydrobiologia 421, 1-24 (2000).

66. Koff, T. \& Vandel, E. Spatial distribution of macrofossil assemblages in surface sediments of two small lakes in Estonia. Estonian J. Ecol. 57, 5-20 (2008).

67. Seppä, H. \& Birks, H. J. B. holocene climate reconstructions from the fennoscandian tree-line area based on pollen data from Toskaljavri. Quat. Res 57, 191-199 (2002).

\section{Acknowledgements}

We acknowledge funding from the Academy of Finland (for MV CLICHÉ-project grant no. 1140900; for J.S.S., project no. 278692), Finnish Cultural Foundation (for J.S.S.), Estonian Research Council (for L.A., A.P. and S.V.; institutional funding IUT 1-8), Estonian Science Foundation (for L.A., A.P. and S.V.; grant ETF-8552), the INTIMATE COST Action ES 0907 (for S.S.; STSM funding), Swedish Nuclear Fuel and Waste Management Company (S.K.B.) and the Bolin Centre for Climate Research (BBCC) at Stockholm University, Sweden (for K.H.). Tarmo Virtanen kindly provided climate data and the map of modern $T_{\text {jul }}$ in Finland.

\section{Author contributions}

M.V. had the main responsibility for the design and writing of the manuscript together with H.H.B., J.S.S. and M.H. J.S.S. performed all the quantitative pollen temperature reconstructions. All co-authors participated, commented and provided contributions relevant to their own data.

\section{Additional information}

Supplementary Information accompanies this paper at http://www.nature.com/ naturecommunications

Competing financial interests: The authors declare no competing financial interests.

Reprints and permission information is available online at http://npg.nature.com/ reprintsandpermissions/

How to cite this article: Väliranta, M. et al. Plant macrofossil evidence for an early onset of the Holocene summer thermal maximum in northernmost Europe. Nat. Commun. 6:6809 doi: 10.1038/ncomms7809 (2015).

(c) (i) This work is licensed under a Creative Commons Attribution 4.0 International License. The images or other third party material in this article are included in the article's Creative Commons license, unless indicated otherwise in the credit line; if the material is not included under the Creative Commons license, users will need to obtain permission from the license holder to reproduce the material. To view a copy of this license, visit http://creativecommons.org/licenses/by/4.0/ 